BANDAZHEVSKY Yu.I. ${ }^{1}$, DUBOVAYA N.F. ${ }^{2 凶}$

${ }^{1}$ PI Coordination and Analytical Center «Ecology and health», Ukraine,07200, urban village Ivankov, Polysskay str., 65, e-mail: Yuri.by375@gmail.com

${ }^{2}$ Shupyk National Medical Academy of Postgraduate Education, Ukraine, 04112, Kyiv,Dorohozhytskaya str., 9, e-mail:n_dubova@i.ua

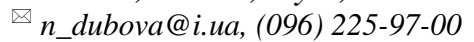

\title{
FOLATE CYCLE GENOME AND CHANGE IN THE HOMOCYSTEINE LEVEL IN CHILDREN AFTER FOREST FIRES IN THE CHERNOBYL EXCLUSION ZONE
}

Fires that often occur in the forests of the Chernobyl Exclusion Zone are one of the most powerful sources of secondary air contamination with combustion products and various radionuclides that have a negative effect on the health of children and adults. Aim. Aim was to explore the relationship between forest fires and the change in blood homocysteine levels in children living in Polessky district of Ukraine bordering the Chernobyl Exclusion Zone. Methods. Immunochemical, mathematical and statistical. Results. Increased blood levels of homocysteine, irrespective of the state of genome of folate cicle, were found in more than $70.0 \%$ of cases in the group of children living near the Chernobyl Exclusion Zone during the period from 02/04/2015 to $18 / 12 / 2015$. Given the forest fires with an area of 10.127 ha and 130 ha officially registered in the Chernobyl exclusion zone in the spring and summer of 2015, it can reasonably be argued that the increase in the level of homocysteine in the blood of children living in the border region associatared with wood burning particles, including black carbon and radioactive elements, that enter the body with air and food. Conclusions. Forest fires in the Chernobyl Exclusion Zone are the cause of abnormal methionine metabolism and an increase in blood homocysteine levels in children from the adjacent districts.

Keywords: homocysteine, folate metabolism, genetic polymorphisms, association, forest fires, Chernobyl Exclusion Zone.

Fires that often occur in the forests of the Chernobyl Exclusion Zone are one of the most powerful sources of secondary air contamination with combustion products and various radionuclides that have a negative effect on human health [1].

It is known that a level of sulphur-containing amino acid homocysteine increases in the blood of elderly men under the influence of wood burning particles (black carbon), which leads to the devel- opment of oxidative stress [2] and damage to the cardiovascular system [3].

In this regard, it is reasonable to determine the influence of forest fires on homocysteine metabolism in residents of districts adjacent to the Chernobyl Exclusion Zone, especially in children.

The aim of this study was to explore the relationship between forest fires and the change in blood homocysteine levels in children living in a Polessky district of Ukraine bordering the Chernobyl Exclusion Zone.

\section{Materials and methods}

The study was conducted within projects of the European Commission in Ukraine «Health and Ecological Programmes around the Chernobyl Exclusion Zone: Development, Training and Coordination of Health-Related Projects» and the RhpneAlpes Regional Council (France).

The examined group comprised 84 children (39 boys and 45 girls) living on the territory of Ukraine after the Chernobyl accident in a Polessky district with ${ }^{137} \mathrm{Cs}$ soil contamination level of $<2$ $\mathrm{Cu} / \mathrm{km}^{2}$ [4] and bordering the Chernobyl Exclusion Zone.

The children's average age at the time of examination was $15.5 \pm 0.1$ years (95\% CI 15.4-15.7 years).

In order to determine homocysteine concentrations and conduct genetic analysis of folate metabolism (FM) each child had blood drawn from the ulnar vein after fasting in the morning twice on 02/04/2015 and 18/12/2015.

The blood samples were analysed at a laboratory certified under quality standards with the agreement of the parents.

Blood homocysteine concentrations were measured using a chemiluminescent immunoassay (CLIA) method. Analyser and test kit: Architect 1000 (ABBOT Diagnostics (USA)). Blood homo-

\footnotetext{
${ }^{\circ}$ BANDAZHEVSKY YU.I., DUBOVAYA N.F.
} 
cysteine levels of over $10 \mu \mathrm{mol} / \mathrm{L}$ were defined as hyperhomocysteinemia.

The following allelic variants were identified during genetic analysis of FM: C677T and A1298C of the MTHFR gene (methylenetetrahydrofolate reductase), A2756G of the MTR gene $\left(\mathrm{B}_{12}\right.$-dependent methionine synthase) and $\mathrm{A} 66 \mathrm{G}$ of the MTRR gene (methionine synthase reductase). A real-time PCR method was used. Analyser and test kit: DT-96 detecting thermocycler, DNA-Technology (Russia).

The statistical processing of the results obtained was performed using the IBM SPSS Statistics 22 software (USA). The arithmetic mean (M), standard error of mean $(\mathrm{m})$, confidence interval for the mean value $(95 \% \mathrm{CI})$, median $(\mathrm{Me})$, interquartile range (IR), minimum and maximum parameter values and percentiles were calculated for the variables analysed. The distribution hypothesis was tested (a Kolmogorov-Smirnov test). Not all of the parameters under study conformed to the normal distribution law, thus the non-parametric Wilcoxon T-test were used to compare values. The statistical significance of variables was assessed by determining a significance level for $\mathrm{p}$ with the help of the statistical software programme. The Student's t-test was used to compare relative values. The critical level of significance for the null hypothesis $(p)$ was set at 0.05 .

\section{Results and discussion}

Blood homocysteine levels in the children from a total group and all the identified genetic subgroups measured on 18/12/2015 were statistically higher than measured on 02/04/2015 (Tables 1,2).

The statistically significant elevation in the proportion of cases of hyperhomocysteinemia during the second measurement compared to the first one was recorded in the total group, as well as in all the subgroups except the subgroup 4 - carriers of genotypes that include the $\mathrm{C}$ risk allele of the MTHFR:A1298C polymorphism (Tables 3, 4).

The proportion of cases of increased blood levels of homocysteine of more than $70.0 \%$ was observed in the total group of children and in all the analysed genetic subgroups both with homozygous carriership of neutral alleles and risk alleles (Table 5).

Table 1. Statistical characteristics of blood homocysteine values in children with different genotypes before and after fires in the Chernobyl Exclusion Zone

\begin{tabular}{|c|c|c|c|c|c|c|}
\hline \multirow[t]{2}{*}{ Subgroup } & \multirow[t]{2}{*}{ Genotype } & \multirow{2}{*}{$\begin{array}{c}\text { Number of children in } \\
\text { subgroups }\end{array}$} & \multicolumn{2}{|c|}{$\begin{array}{c}\mathrm{H}_{\mathrm{c}} 1(\mu \mathrm{mol} / \mathrm{L}) \\
02 / 04 / 2015 \\
\end{array}$} & \multicolumn{2}{|c|}{$\begin{array}{c}\mathrm{H}_{\mathrm{c}} 2(\mu \mathrm{mol} / \mathrm{L}) \\
18 / 12 / 2015\end{array}$} \\
\hline & & & $\mathrm{Me}$ & IR & $\mathrm{Me}$ & IR \\
\hline 1 & MTR:2756 A/A & 57 & 10.7 & $9.0-14.1$ & 12.8 & $11.2-15.8$ \\
\hline 2 & $\begin{array}{l}\text { MTR:2756 A/G, } \\
\text { MTR:2756 G/G }\end{array}$ & 27 & 9.6 & 7.9-11.0 & 10.9 & $9.9-13.0$ \\
\hline 3 & MTHFR:1298 A/A & 47 & 10.3 & $8.0-13.3$ & 12.6 & $10.9-14.5$ \\
\hline 4 & $\begin{array}{l}\text { MTHFR:1298 A/C, } \\
\text { MTHFR:1298 C/C }\end{array}$ & 37 & 10.4 & $8.3-12.9$ & 11.7 & $9.8-14.4$ \\
\hline 5 & MTHFR:677 C/C & 44 & 9.7 & 7.7-11.1 & 11.4 & $9.7-14.1$ \\
\hline 6 & $\begin{array}{l}\text { MTHFR:677 C/T, } \\
\text { MTHFR:677 T/T }\end{array}$ & 40 & 11.4 & 9.4-14.4 & 12.8 & $11.0-15.2$ \\
\hline 7 & MTRR:66 A/A & 17 & 9.3 & $7.2-13.0$ & 11.5 & $9.8-13.0$ \\
\hline 8 & $\begin{array}{l}\text { MTRR:66 A/G, } \\
\text { MTRR:66 G/G }\end{array}$ & 67 & 10.7 & $9.0-13.1$ & 12.5 & $10.6-14.8$ \\
\hline 9 & \begin{tabular}{|l|} 
MTR:2756 A/A - \\
MTHFR:677 C/C \\
\end{tabular} & 33 & 9.7 & $7.5-12.2$ & 12.5 & $10.0-14.9$ \\
\hline 10 & $\begin{array}{l}\text { MTR:2756 A/G, } \\
\text { MTR:2756 G/G - } \\
\text { MTHFR:677 C/T, } \\
\text { MTHFR:677 T/T }\end{array}$ & 16 & 10.2 & $8.2-11.7$ & 12.2 & $10.3-13.4$ \\
\hline & otal group & 84 & 10.3 & $8.0-13.1$ & 12.3 & $10.4-14.5$ \\
\hline
\end{tabular}


Folate cycle genome and change in the homocysteine level in children after forest fires in the Chernobyl exclusion zone

Table 2. Results of non-parametric comparative analysis (Wilcoxon T-test) of two samples of homocysteine $\left(\mathrm{H}_{\mathrm{c}} 1\right.$ and $\left.\mathrm{H}_{\mathrm{c}} 2\right)$

\begin{tabular}{|c|l|c|c|}
\hline Subgroup & \multicolumn{1}{|c|}{ Genotype } & $\begin{array}{c}\text { Standardised value of } \\
\text { Wilcoxon T-test, } \mathrm{Z}\end{array}$ & $\begin{array}{c}\text { Asymptotic significance (2- } \\
\text { sided), } \mathrm{p}\end{array}$ \\
\hline 1 & MTR:2756 A/A & -4.660 & $\mathrm{p}=0.0001$ \\
\hline 2 & $\begin{array}{l}\text { MTR:2756 A/G, } \\
\text { MTR:2756 G/G }\end{array}$ & -3.039 & $\mathrm{p}=0.002$ \\
\hline 3 & MTHFR:1298 A/A & -4.318 & $\mathrm{p}=0.0001$ \\
\hline 4 & $\begin{array}{l}\text { MTHFR:1298 A/C, } \\
\text { MTHFR:1298 C/C }\end{array}$ & -3.432 & $\mathrm{p}=0.001$ \\
\hline 5 & MTHFR:677 C/C & -4.773 & $\mathrm{p}=0.0001$ \\
\hline 6 & $\begin{array}{l}\text { MTHFR:677 C/T, } \\
\text { MTHFR:677 T/T }\end{array}$ & -3.118 & $\mathrm{p}=0.002$ \\
\hline 7 & MTRR:66 A/A & -2.391 & $\mathrm{p}=0.0001$ \\
\hline 8 & $\begin{array}{l}\text { MTRR:66 A/G, } \\
\text { MTRR:66 G/G }\end{array}$ & -5.125 & $\mathrm{p}=0.0001$ \\
\hline 9 & $\begin{array}{l}\text { MTR:2756 A/A- } \\
\text { MTHFR:677 C/C }\end{array}$ & -4.440 & $\mathrm{p}=0.010$ \\
\hline 10 & $\begin{array}{l}\text { MTR:2756 A/G, } \\
\text { MTR:2756 G/G - } \\
\text { MTHFR:677 C/T, } \\
\text { MTHFR:677 T/T }\end{array}$ & -2.585 & $\mathrm{p}=0.0001$ \\
\hline
\end{tabular}

Table 3. Dynamics of hyperhomocysteinemia cases in subgroups of children with different genotypes

\begin{tabular}{|c|c|c|c|c|c|c|c|}
\hline \multirow{3}{*}{ Subgroup } & \multirow{3}{*}{$\begin{array}{c}\text { Number of } \\
\text { cases }\end{array}$} & \multicolumn{6}{|c|}{ Hyperhomocysteinemia } \\
\hline & & \multicolumn{2}{|c|}{ Measurement 1} & \multicolumn{2}{|c|}{ Measurement 2} & \multicolumn{2}{|c|}{ Increment } \\
\hline & & $\begin{array}{l}\text { Absolute } \\
\text { number }\end{array}$ & $\%$ & $\begin{array}{l}\text { Absolute } \\
\text { number }\end{array}$ & $\%$ & $\begin{array}{l}\text { Absolute } \\
\text { number }\end{array}$ & $\%$ \\
\hline 1 & 57 & 35 & 61.4 & 47 & 82.5 & 12 & 21.1 \\
\hline 2 & 27 & 13 & 48.2 & 20 & 74.1 & 7 & 25.9 \\
\hline 3 & 47 & 26 & 55.3 & 41 & 87.2 & 15 & 31.9 \\
\hline 4 & 37 & 22 & 59.5 & 26 & 70.3 & 4 & 10.8 \\
\hline 5 & 44 & 20 & 45.5 & 31 & 70.5 & 11 & 25.0 \\
\hline 6 & 40 & 28 & 70.0 & 36 & 90.0 & 8 & 20.0 \\
\hline 7 & 17 & 7 & 41.2 & 13 & 76.5 & 6 & 35.3 \\
\hline 8 & 67 & 41 & 61.2 & 54 & 80.6 & 13 & 19.4 \\
\hline 9 & 33 & 16 & 48.5 & 25 & 75.8 & 9 & 27.3 \\
\hline 10 & 16 & 9 & 56.3 & 14 & 87.5 & 5 & 31.2 \\
\hline Total group & 84 & 48 & 57.2 & 67 & 79.8 & 19 & 22.6 \\
\hline
\end{tabular}

On the basis of these findings, we can state that there was an increase in blood homocysteine levels in the children living in the Polessky district adjacent to the Chernobyl Exclusion Zone during the period from $02 / 04 / 2015$ to $18 / 12 / 2015$.

A statistically significant increase in the lev- els of this metabolite was reported both in the total group and in separate genetic subgroups. Similar dynamics was observed with regard to hyperhomocysteinemia cases in the total group of children and in the majority of the genetic subgroups under analysis as well. 
Table 4. Results of comparison of proportions of hyperhomocysteinemia cases in subgroups of children with different genotypes having two measurements of homocysteine concentrations

\begin{tabular}{|c|l|c|c|}
\hline Subgroup & \multicolumn{1}{|c|}{ Genotype } & $\mathrm{t}$ & $\mathrm{p}$ \\
\hline 1 & MTR:2756 A/A & 2.57 & 0.011955 \\
\hline 2 & MTR:2756 A/G, MTR:2756 G/G & 2.03 & 0.051264 \\
\hline 3 & MTHFR:1298 A/A & 3.63 & 0.000567 \\
\hline 4 & MTHFR:1298 A/C, MTHFR:1298 C/C & 0.98 & 0.333133 \\
\hline 5 & MTHFR:677 C/C & 2.45 & 0.017846 \\
\hline 6 & MTHFR:677 C/T, MTHFR:677 T/T & 2.30 & 0.024669 \\
\hline 7 & MTRR:66 A/A & 2.24 & 0.038520 \\
\hline 8 & MTRR:66 A/G, MTRR:66 G/G & 2.52 & 0.013288 \\
\hline 9 & MTR:2756 A/A- MTHFR:677 C/C & 2.37 & 0.023113 \\
\hline \multirow{2}{*}{10} & MTR:2756 A/G, MTR:2756 G/G - & 2.09 & 0.049505 \\
\hline & MTHFR:677 C/T, MTHFR:677 T/T & 3.26 & 0.001481 \\
\hline
\end{tabular}

In this regard, one should mention a Subgroup 9, which contains cases of simultaneous carriership of homozygotes of neutral alleles of the MTR:2756 and MTHFR:677 polymorphisms regulating homocysteine methylation processes. Thus, an increase in the level of homocysteine in the blood and the number of cases of hyperhomocysteinemia indicates that there has been an environmental impact on the body of children from this Subgroup.

The most probable cause of the increase in blood homocysteine levels in most children is the forest fires occurred in the Chernobyl Exclusion
Zone in the spring and summer of 2015. The forest and peat fires in the Chernobyl Exclusion Zone were officially recorded during the periods 26$27 / 04 / 2015$ and $28-29 / 04 / 2015$ in an area of 10127 hectares [5] and during the period 29/06/2015 to 05/07/2015 in an area of 130 hectares [6].

During the fires, the combustion products of wood and peat in the form of finely dispersed particles of 0.1-2.5 micrometers (PM2.5), including black carbon, can penetrate into the respiratory tract of residents of localities situated near the Chernobyl Exclusion Zone, reaching the bronchioles and alveoli [7].

Table 5. Proportion of cases of increased blood levels of homocysteine in subgroups of children with different genotypes

\begin{tabular}{|c|l|c|c|c|}
\hline \multirow{2}{*}{ Subgroup } & \multicolumn{1}{|c|}{ Genotype } & \multirow{2}{*}{$\begin{array}{c}\text { Number } \\
\text { of cases }\end{array}$} & \multicolumn{2}{|c|}{$\begin{array}{c}\text { Increased blood levels of } \\
\text { homocysteine }\end{array}$} \\
\cline { 4 - 5 } & & 57 & 46 & Absolute number \\
\hline 1 & MTR:2756 A/A & 27 & 23 & 80.7 \\
\hline 2 & MTR:2756 A/G, MTR:2756 G/G & 47 & 40 & 85.2 \\
\hline 3 & MTHFR:1298 A/A & 37 & 28 & 75.7 \\
\hline 4 & MTHFR:1298 A/C, MTHFR:1298 C/C & 44 & 38 & 86.4 \\
\hline 5 & MTHFR:677 C/C & 40 & 29 & 72.5 \\
\hline 6 & MTHFR:677 C/T,MTHFR:677 T/T & 17 & 13 & 76.5 \\
\hline 7 & MTRR:66 A/A & 67 & 55 & 82.1 \\
\hline 8 & MTRR:66 A/G, MTRR:66 G/G & 33 & 29 & 87.9 \\
\hline 9 & MTR:2756 A/A - MTHFR:677 C/C & 16 & 14 & 87.5 \\
\hline 10 & MTR:2756 A/G, MTR:2756 G/G - & 84 & 67 & 79.8 \\
\hline
\end{tabular}


At the same time, it is necessary to take into account the effect of radionuclides contained in the combustion products of wood. In 2015 in the areas of ground forest fires in sections 306-308 of Lubyanka Forest Division located on the territory of the Chernobyl Exclusion Zone the maximum contamination density of the territory was 1040 $\mathrm{kBq} / \mathrm{m}^{2}$ for ${ }^{137} \mathrm{Cs} ; 368 \mathrm{kBq} / \mathrm{m}^{2}$ for ${ }^{90} \mathrm{Sr} ; 11.4 \mathrm{kBq} / \mathrm{m}^{2}$ for ${ }^{238,240} \mathrm{Pu} ; 14.4 \mathrm{kBq} / \mathrm{m}^{2}$ for ${ }^{241} \mathrm{Am}$ [5]. It is logical to assume that these radionuclides as part of woodburning particles were spreading with air currents beyond fire fronts over great distances and had a negative impact on the health of children and adults in remote areas.

\section{Conclusions}

\section{References}

1. Azarov S.I., Sydorenko V.L., Rudenko O.V. Vyvchennia protsesu nadkhodzhennia radionuklidiv u povitria pry pozhezhakh u lisakh zony vidchuzhennia ChAES. Problemy pozharnoy bezopasnosty: sbornyk nauchnykh trudov. Kyiv, 2011. Vyp. 30. S. 16-23. [in Ukrainian] / Азаров С.І., Сидоренко В.Л., Руденко О.В. Вивчення процесу надходження радіонуклідів у повітря при пожежах у лісах зони відчуження ЧАЕС. Проблемы пожарной безопасности: сборник научных трудов. К., 2011. Вып. 30. С. 16-23.

2. Ren C., Park S., Vokonas P., Sparrow D. et al. Air Pollution and Homocysteine: More Evidence that Oxidative Stress-related Genes Modify Effects of Particulate Air Pollution. Epidemiology. 2010. Vol. 21, № 2. P. 198-206.

3. Park S.K., O'Neill M.S., Vokonas P.S. et al. Trafficrelated particles are associated with elevated homocysteine. The VA Normative Aging Study. Am. J. Respir. Crit. Care Med. 2008. Vol. 178. P. $283-289$.

4. Zahal'nodozymetrychna pasportyzatsiia ta rezul'taty LVL-monitorynhu $\mathrm{v}$ naselenykh punktakh Ukrainy, iaki zaznaly radioaktyvnoho zabrudnennia pislia Chornobyl's'koi katastrofy. Dani za 2011 r. Zbirka 14. Kyiv: MOZ Ukrainy, NAMNU Ukrainy, MNS Ukrainy, DAZV, DU "NNTsRM NAMN Ukrainy", ND IRZ ATN Ukrainy, 2012. 99 s. [in Ukrainian] / Загальнодозиметрична паспортизація та результати ЛВЛ-моніторингу в населених пунктах України, які зазнали радіоактивного забруднення після Чорнобильської катастрофи. Дані за 2011 р. Збірка 14. К. МОЗ України, НАМНУ України, МНС України, ДАЗВ, ДУ «ННЦРМ НАМН України», НД IРЗ АТН України, 2012. 99 с.

5. Kashparov V.A., Mironiuk V.V., Zhurba M.A. i dr. Radiologicheskie posledstviia pozhara v Chernobyl'skoy zone otchuzhdeniia v aprele 2015 goda. Radiatsionnaia biologiia. Radioekologiia. 2017. T. 57, No. 5. S. 512-527. [in Russian] / Кашпаров В.А., Миронюк В.В., Журба М.А. и др. Радиологические последствия пожара в Чернобыльской зоне отчуждения в апреле 2015 года. Радиачионная биология. Радиоэкология. 2017. Т. 57. № 5. С. 512-527.

6. Bogorad V.I., Litvinskaia T.V., Shevchenko I.A., Dybach A.M., Slepchenko A.Iu. Radiatsionnye posledstviia pozhara v zone otchuzhdeniia Chernobyl'skoy AES. Iaderna ta radiatsiyna bezpeka. 2016. T. 69, No. 1. S. 64-68. [in Russian] / Богорад В.И., Литвинская Т.В., Шевченко И.А., Дыбач А.М., Слепченко А.Ю. Радиационные последствия пожара в зоне отчуждения Чернобыльской АЭС. Ядерна та радіаційна безпека. 2016. Т. 69, № 1. С. 64-68.

7. Kolpakova A.F., Sharipov R.N., Volkova O.A. Vliianie zagriazneniia atmosfernogo vozdukha vzveshennymi veshchestvami na serdechno-sosudistuiu sistemu. Sibirskiy meditsinskiy zhurnal. 2015. T. 30, No. 3. S. 7-12. [in Russian] / Колпакова А.Ф., Шарипов Р.Н., Волкова О.А. Влияние загрязнения атмосферного воздуха взвешенными веществами на сердечнососудистую систему. Сибирский медищинский журнал. 2015. Т. 30, № 3. С. 7-12.

\section{БАНДАЖЕВСЬКИЙ Ю.І. ${ }^{1}$, ДУБОВА Н.Ф. ${ }^{2}$}

${ }^{1}$ Координаційно-аналітичний изентр «Екологія та здоров'я»,

Україна, 07200, смт. Іванків, вул. Поліська, 65, е-таil: Yuri.by375@gmail.com

${ }^{2}$ Національна медична академія післядипломної освіти ім. П.Л. Шупика МОЗ Украӥни,

Україна, 04112, м. Київ, вул. Дорогожищька, 9, е-таil:n_dubova@i.иа

\section{ГЕНОМ ФОЛАТНОГО ЦИКЛУ І ЗМІНА РІВНЯ ГОМОЦИСТЕЇНУ У ДІТЕЙ ПІСЛЯ ЛІСОВИХ ПОЖЕЖ У ЧОРНОБИЛЬСЬКІЙ ЗОНІ ВІДЧУЖЕННЯ}

Пожежі, що часто виникають в лісових масивах Чорнобильської зони відчуження, є одним з найпотужніших джерел вторинного забруднення повітря продуктами горіння і радіонуклідами різного виду, що чинять негативний вплив на здоров'я дитячого та дорослого населення. Мета. Метою було визначення зв'язку між лісовими пожежами і зміною рівня гомоцистеїну в крові дітей, які проживають у Поліському районі України, що межує 3 Чорнобильською зоною відчуження. Методи. Імунохімічний, математико-статистичний. Результати. У більш 
ніж 70,0 \% випадків, виявлено незалежне від стану геному фолатного циклу підвищення рівня гомоцистеїну в крові дітей однієї і тієї ж групи, що мешкають поблизу Чорнобильської зони відчуження, у період між 02.04.2015 та 18.12.2015 року. 3 огляду на пожежі лісу, площею 10127 і 130 га, офіційно зареєстрованих на території Чорнобильської зони відчуження у весняно-літній період 2015 року, можна обгрунтовано стверджувати те, що підвищення рівня гомоцистеїну в крові дітей, які проживають у прикордонному районі, пов'язане 3 частинками горіння деревини, включають чорний вуглець і радіоактивні елементи, що проникають в організм 3 повітрям та їею. Висновки. Лісові пожежі в Чорнобильській зоні відчуження є причиною порушення обміну метіоніну і підвищення рівня гомоцистеїну в крові дітей з прилеглих районів.

Ключові слова: гомоцистеїн, фолатний цикл, генетичні поліморфізми, лісові пожежі, Чорнобильська зона відчуження. 